\title{
The tadpole of Dendropsophus haddadi (Amphibia, Anura, Hylidae): additions on morphological traits and comparisons with tadpoles of the $D$. decipiens and D. microcephalus species groups
}

\author{
Rafael Oliveira de Abreu ${ }^{1 *}$, Marcelo Felgueiras Napoli ${ }^{2,3}$, Milena Camardelli ${ }^{1}$ \& Patricia Mendes Fonseca ${ }^{1}$ \\ ${ }^{1}$ Programa de Pós-Graduação em Diversidade Animal e ${ }^{2}$ Museu de Zoologia. Departamento de Zoologia, \\ Instituto de Biologia, Universidade Federal da Bahia, Salvador, Bahia, Brasil. \\ ${ }^{3}$ Departamento de Vertebrados, Museu Nacional, Universidade Federal do Rio de Janeiro, Rio de Janeiro, Brasil
}

\begin{abstract}
The Dendropsophus decipiens species group, placed in the D. microcephalus species clade, comprises D. decipiens, D. berthalutzae, D. oliveirai and D. haddadi, which have their larvae already described in the literature. In this account, we describe the variation of the tadpole of $D$. haddadi from the Municipality of Mata de São João, State of Bahia, Brazil. We also compare this tadpole to the larvae of the $D$. decipiens and $D$. microcephalus species groups already described.

Additional key words: Bahia State, Hylinae, morphology.
\end{abstract}

Resumo (O girino de Dendropsophus haddadi (Amphibia, Anura, Hylidae): adições sobre características morfológicas e comparações com girinos dos grupos de espécies de D. decipiens e D. microcephalus) - O grupo de espécies de Dendropsophus decipiens, posicionado no clado de $D$. microcephalus, compreende $D$. decipiens, D. berthalutzae, D. oliveirai e $D$. haddadi, que têm suas larvas já descritas na literatura. No presente trabalho, descrevemos a variação do girino de D. haddadi oriundo do Município de Mata de São João, estado da Bahia, Brasil. Também, comparamos este girino às larvas dos grupos de espécies de D. decipiens e D. microcephalus já descritas na literatura.

Palavras-chave adicionais: Bahia, Hylinae, morfologia.

The Dendropsophus decipiens species group (sensu Carvalho-e-Silva et al. 2003) is comprised by four species: D. decipiens (Lutz, 1925), D. berthalutzae (Bokermann, 1962), D. oliveirai (Bokermann, 1963) and D. haddadi (Bastos \& Pombal, 1996). This species group was is included in the $D$. microcephalus clade (sensu Faivovich et al. 2005) and is distributed along the coastal region of eastern Brazil, from the State of Pernambuco to the State of Rio de Janeiro (Frost 2013). All species of the $D$. decipiens group have their larvae already described (Bokermann 1963; Pugliese et al. 2000; Lourenço-de-Moraes et al. 2012). The tadpole of $D$. haddadi is the most recently known form, which was described by Lourenço-de-Moraes et al. (2012) using specimens from the Capitão Private Reserve of Natural Heritage (RPPN), Municipality of Itacaré $\left(14^{\circ} 19^{\prime} \mathrm{S}, 39^{\circ} 04^{\prime} \mathrm{W}\right)$, State of Bahia, Brazil. In the present account, we provide additions on color and morphological traits to the description of the Dendropsophus haddadi tadpole using specimens from the Municipality of Mata de São João, State of Bahia, Brazil, and compare it to the remaining larvae of the $D$. decipiens and D. microcephalus species groups.

The analysis and description of the external morphology of Dendropsophus haddadi tadpoles was based on 26 specimens in stages 28-37 (Gosner 1960) obtained from hatches of amplected pairs of $D$. haddadi.

\footnotetext{
"Corresponding author: rafaoabreu@gmail.com

Corresponding editor: Flora A. Juncá

Submitted: 5 Mar 2013; accepted: 4 June 2013

First published: 18 July 2013; final version: 2 May 2014
}

All examined tadpoles of $D$. haddadi are housed at the Museu de Zoologia da Universidade Federal da Bahia (UFBA), Municipality of Salvador, State of Bahia, Brazil. All individuals were fixed in $4 \%$ formalin. We measured 17 morphometric characters, using an ocular micrometer in a stereomicroscope. Nomenclature of morphological characteristics follows Altig \& McDiarmid (1999).

Material examined - BRAZIL. BAHIA. Municipality of Mata de São João: Açu da Torre, fazenda Camurujipe (12 $\left.53^{\circ} \mathrm{S}, 38^{\circ} 29^{\prime} \mathrm{W}\right)$, 20-27 May 2006, M. Camardelli et al., UFBA 8029 (12 tadpoles), UFBA 8030 (8 tadpoles), UFBA 8031 (5 tadpoles), UFBA 11763 (1 tadpole)

\section{DESCRIPTION OF TADPOLE}

External morphology (Figure 1; Table 1). Total length $15.5-20.4$ in stages 28 to 37 . Body depressed, oval in lateral view (longer in some individuals), shortened, almost round to elliptic in dorsal view. Body length 35-38\% of total length; body height $52-66 \%$ of body length and $87-117 \%$ of tail height. Snout round in dorsal view, almost flat, with two reentrances where nares are placed. Nares round, frontally positioned, internarial distance $50-51 \%$ of maximum body width. Tail length $56-74 \%$ of total length, with acute tip. Dorsal fin starts at the posterior third of body, close to body-tail junction, dorsal fin height almost equal to the height of ventral fin. Eyes lateral, positioned at the end of anterior third of body, 

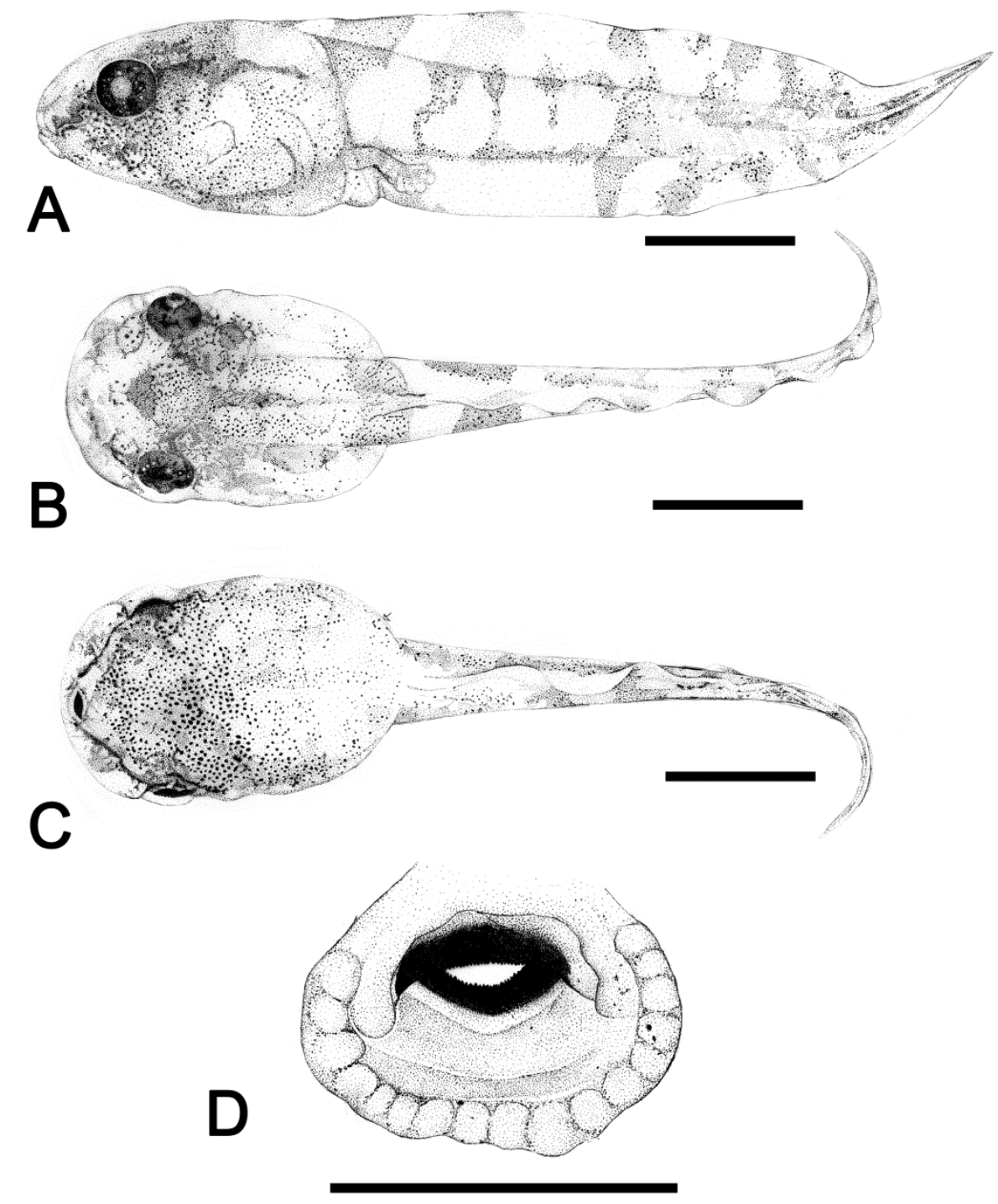

Figure 1. Tadpole of Dendropsophus haddadi, from Mata de São João, State of Bahia, Brazil (UFBA 11763, stage 35): A- lateral view; B-C- dorsal view; D- oral disc (bars: A-C $=3 \mathrm{~mm}$; D = $1 \mathrm{~mm}$ ).

above half the height of body, its diameter $15-19 \%$ of body length. Spiracle short, sinistral, positioned on the medial third of body, below the height of eye on the body, with opening posteriorly directed. Vent tube short, dextrally directed, attached to the ventral fin, hidden by the developing posterior member. Oral disc anteroventral, almost terminal (sensu Duellman 1970), small (oral disc width $<1 / 3$ maximum body width). One row of labial papillae reduced in many individuals, probably caused by the captive maintenance), presence of two ridges in lower lip, without labial teeth. Maxillae wide, entire, free margins arched, serrated and pigmented black. Upper maxilla with more arched free margin, projected in front of the lower maxilla.

Color in life. Background color of body orange. Venter silver until the first third of body, from which the background color fades. Body almost completely covered by a dark brown or black blur (sometimes fragmented) with posterior limit extending diagonally from venter to the most anterior region of tail musculature and dorsal fin. Discolored areas expose the background color on dorsum: anterior to eyes, almost "U-shaped"; on oral disc, as a thin line towards eye (sometimes not reaching or trespassing the eye); on visceral region of venter, where is marbled-like, and; close to the half of body, as a diagonal triangular band that rises from venter extending and enlarging posterodorsally to the body-tail junction (in some individuals the discoloured band is reduced). A black diagonal line, darker than the black blur that covers the body, extends and straightens from oral disc, trough eye towards the half of the body. Scattered small bright silver, yellow or green dots cover body, dorsum of tail musculature (closer to body-tail junction) and first $1 / 5$ of dorsal fin and fin margins. Tail orange with dark brown scattered dots (the same described by Lourenço- 
Table 1. Descriptive statistics (means \pm standard deviation) of tadpoles of Dendropsophus haddadi. Number of stage of development (Gosner 1960) followed by number of individuals measured in parenthesis. BH- maximum body height; BL- body length; BW- maximum body width; END- eye-nostril distance; ESD- eye-snout distance; IND- internarial distance; MTH- maximum tail height; NSD- nostril-tip of snout distance; TAL- tail length; TL- total length; TMH- tail muscle height. Following Mercês \& Juncá (2010): DFH- dorsal fin height; ED- eye diameter; ODW- oral disc width; SSD- spiracle-snout distance; VFH- ventral fin height. Following Nascimento et al. (2010): IOD- interorbital distance.

\begin{tabular}{|c|c|c|c|c|c|c|c|c|}
\hline STAGE & $\begin{array}{c}28 \\
(\mathrm{n}=1)\end{array}$ & $\begin{array}{c}30 \\
(\mathrm{n}=1)\end{array}$ & $\begin{array}{c}31 \\
(n=1)\end{array}$ & $\begin{array}{c}32 \\
(n=4)\end{array}$ & $\begin{array}{c}33 \\
(\mathrm{n}=3)\end{array}$ & $\begin{array}{c}35 \\
(\mathrm{n}=12)\end{array}$ & $\begin{array}{c}36 \\
(n=4)\end{array}$ & $\begin{array}{c}37 \\
(\mathrm{n}=1)\end{array}$ \\
\hline TL & 15.5 & 17.4 & 15.2 & $16.7 \pm 1$ & $18.5 \pm 0.6$ & $17.6 \pm 2.5$ & $19.3 \pm 2.1$ & 20.4 \\
\hline BL & 5.7 & 6.7 & 5.5 & $6.2 \pm 0.6$ & $6.6 \pm 0.3$ & $6.6 \pm 0.6$ & $7.3 \pm 0.3$ & 7.4 \\
\hline TAL & 9.8 & 10.7 & 9.8 & $10.5 \pm 0.4$ & $11.9 \pm 0.4$ & $11.4 \pm 1.4$ & $11.9 \pm 1.9$ & 13.0 \\
\hline МВН & 3.2 & 3.5 & 3.4 & $3.9 \pm 0.3$ & $4.2 \pm 0.1$ & $4.1 \pm 0.5$ & $4.5 \pm 0.3$ & 4.7 \\
\hline МТН & 3.2 & 3.4 & 3.1 & $3.4 \pm 0.1$ & $4.1 \pm 0.3$ & $4.2 \pm 0.4$ & $4.1 \pm 0.2$ & 4.5 \\
\hline DFH & 1.0 & 1.2 & 1.0 & $1.1 \pm 0.1$ & $1.3 \pm 0.2$ & $1.5 \pm 0.2$ & $1.4 \pm 0.1$ & 1.5 \\
\hline VFH & 1.0 & 1.1 & 0.8 & $1.1 \pm 0.2$ & $1.3 \pm 0.2$ & $1.3 \pm 0.2$ & $1.3 \pm 0.1$ & 1.4 \\
\hline MBW & 3.8 & 3.9 & 3.8 & $4.4 \pm 0.4$ & $4.6 \pm 0.2$ & $4.8 \pm 0.6$ & $5.1 \pm 0.2$ & 5.3 \\
\hline ED & 1.0 & 1.0 & 0.9 & $1.0 \pm 0.2$ & $1.2 \pm 0.1$ & $1.2 \pm 0.1$ & $1.3 \pm 0.1$ & 1.3 \\
\hline ODW & 0.9 & 1.1 & 0.9 & $0.8 \pm 0.1$ & $1.1 \pm 0.2$ & $1.1 \pm 0.2$ & $1.3 \pm 0.2$ & 1.1 \\
\hline STD & 1.4 & 2.0 & 1.8 & $2.0 \pm 0.2$ & $2.0 \pm 0.2$ & $2.2 \pm 0.3$ & $2.3 \pm 0.1$ & 2.2 \\
\hline SSD & 4.2 & 4.2 & 3.7 & $4.2 \pm 0.4$ & $4.6 \pm 0.5$ & $4.5 \pm 0.4$ & $5.6 \pm 0.8$ & 5.3 \\
\hline IOD & 1.9 & 2.0 & 2.1 & $2.2 \pm 0.2$ & $2.5 \pm 0.2$ & $2.6 \pm 0.3$ & $2.7 \pm 0.1$ & 2.8 \\
\hline ESD & 1.6 & 1.8 & 1.2 & $1.6 \pm 0.4$ & $1.8 \pm 0.3$ & $1.9 \pm 0.2$ & $2.0 \pm 0.1$ & 1.9 \\
\hline END & 0.8 & 1.3 & 0.7 & $0.8 \pm 0.1$ & $1.3 \pm 0.1$ & $1.1 \pm 0.2$ & $1.2 \pm 0.3$ & 1.2 \\
\hline IND & 2.0 & 2.4 & 2.0 & $2.2 \pm 0.2$ & $2.4 \pm 0.2$ & $2.4 \pm 0.4$ & $2.5 \pm 0.3$ & 2.6 \\
\hline NSD & 1.1 & 1.3 & 1.2 & $1.2 \pm 0.2$ & $1.2 \pm 0.1$ & $1.3 \pm 0.2$ & $1.4 \pm 0.1$ & 1.4 \\
\hline
\end{tabular}

de-Moraes et al. 2012 ) or with dark brown or black blurs that varies in shape as thin irregular vertical bands (sometimes resembling reticulation). Fins more translucent than tail musculature. Limb bud with irregular markings. Eyes in dorsal view black, marbled with silver spots. Iris red, silver on upper and lower thirds, bordered externally with black and internally with the same silver color of the lower third of iris.

Color in preservative. In preservative, the overall color becomes dimmed; background color becomes cream and the dark blurs become clearer (almost disappearing in many individuals), iris becomes black and the black diagonal line that extends from oral disc to the half of the body becomes more evident.

\section{COMPARISONS WITH OTHER SPECIES}

The tadpole of Dendropsophus haddadi described here is similar in external morphology and color pattern to that described by Lourenço-de-Moraes et al. (2012). The only difference is the record of a variation with banded tail in this population sampled from Mata de São João, not reported for the samples from Itacaré (ca. $230 \mathrm{~km}$ from the former locality). The tadpole of $D$. haddadi is similar to those described for the $D$. decipiens species group in color and external morphology. Remarkable resemblances are: 1- body shape depressed, ovoid in lateral view, shortened elliptic to round, in dorsal view; 2- eyes position on the first third of body; 3- tail tip acute; 4- labial papillae present; 5- presence of ridges on lower lip; 6- oral disc not tube-like; 7- color pattern with body uniformly dark, tail banded (sometimes irregular distorted bands), light stripe from oral disk to eye, and ventral light blurs on the first third of body. Remarkable differences with the $D$. decipiens species group are: 1- tail color in $D$. haddadi predominantly orange (sometimes with dark markings), individuals with the irregular bands also in dark brown or black; 2- ornamentation of tail in D. haddadi are from thin, irregular bands to dark brown scattered dots, always large bands on the other species; 3- body brown to black with orange background in $D$. haddadi (similar to D. oliveirai), golden with greenish reflections in one tadpole of $D$. decipiens from Mata de São João and olive in D. berthalutzae; 4- diagonally on body, a discoloured band that exposes the background color is longer and wider in $D$. haddadi than in $D$. decipiens, apparently reduced or absent in D. berthalutzae and D. oliveirai; once it is not reported on description of the former two species.

The tadpole of $D$. haddadi, as the other of the $D$. decipiens species group, differs from the other known tadpoles of the D. microcephalus species group, remarkably by: 1- presence of ridges and papillae on lower lip; 2- oral disk not tube-like as reported for 
D. nanus (Boulenger, 1889) by Lavilla (1990), RossaFeres \& Nomura (2006) and Vera-Candioti (2007), and for D. microcephalus by Vera-Candioti (2007); the same tube-like oral disk was reported as suctorial for D. sanborni (Schmidt, 1944) by Cei (1980) and cuplike for D. sanborni by Bokermann (1963); 3- body ovoid in lateral view and ovoid with shortened snout in dorsal view (vs. longer, triangular in lateral view and oval or "violin-shaped" with snout long in dorsal view); 4- eyes on the first third of body (vs. on the second third); 5 - tail smaller (ca. $65 \%$ vs. ca. $75 \%$ of total length); 6- tail tip acute (vs. flagellum-like); 7- general color pattern characterized by body brown to black with well-marked depigmented areas, and posterior section of body and overall tail with dark brown or black diagonal bands (sometimes irregular bands to dark brown scattered dots), whereas in many species of the D. microcephalus group the body is divided horizontally in two colors: above, homogeneous dark brown, and below, a clearer background color (white, orange, cream), and the tail is almost completely covered by the same brown color of body (the brown color varies from orange to darkest tons of brown among species) with discolored blotches showing background color. Differences 1, 3, 4 and 6 were already reported by Pugliese et al. (2000) when comparing $D$. oliveirai and $D$. decipiens to the species of the D. microcephalus group.

\section{ACKNOWLEDGEMENTS}

We are grateful to F.A. Juncá and U. Caramaschi for critical comments on the first version of the manuscript, and to M. Camardelli, P.M. Fonseca and T. Filadelfo for field assistance. We acknowledge Fundação Garcia D'Ávila and A.A. Paiva for allowing us to access research areas under their care and for logistical assistance at Reserva Camurujipe;. The Instituto Brasileiro do Meio Ambiente e dos Recursos Naturais Renováveis (IBAMA) permitted collection of specimens (license n. 02006.002336/03-26 and 0210.000812/05-84). The Conselho Nacional de Desenvolvimento Científico e Tecnológico (CNPq) awarded fellowship to Marcelo F. Napoli (Proc. 309672/2012-0). The Coordenação de Aperfeiçoamento de Pessoal de Nível Superior (CAPES) and Fundação de Amparo à Pesquisa do Estado da Bahia (FAPESB) awarded fellowship to Rafael O. Abreu

\section{REFERENCES}

Altig, R. \& McDiarmid, R.W. 1999. Body plan: development and morphology. In: R.W. Mc-Diarmid \& R. Altig (eds), Tadpoles: the biology of anuran larvae. University of Chicago Press, Chicago, p. 24-51.

Bokermann, W.C. 1963. Girinos de anfíbios brasileiros (Amphibia - Salientia). Anais da Academia Brasileira de Ciências 35(3): 465-474.

Carvalho-e-Silva, S.P.; Carvalho-e-Silva, A.M.P.T. \& Izecksohn, E. 2003. Nova espécie de Hyla Laurenti do grupo de $H$. microcephala Cope (Amphibia, Anura, Hylidae) do nordeste do Brasil. Revista Brasileira de Zoologia 20(3): 553-558.

Cei, M.J. 1980. Amphibians of Argentina. Monitore Zoologico Italiano, New Series, Monograph 2: 1-609.

Duellman, W.E. 1970. The hylid frogs of Middle America. Monograph of the Museum of Natural History, The University of Kansas.

Faivovich, J.; Haddad, C.F.B.; Garcia, P.C.A.; Frost, D.R.; Campbell, J.A. \& Wheeler, W.C. 2005. Systematic review of the frog family Hylidae, with special reference to Hylinae: phylogenetic analysis and taxonomic revision. Bulletin of the American Museum of Natural History 294: 1-240.

Frost, D.R. 2013. Amphibian Species of the World: an online reference. American Museum of Natural History. Available at $<$ http://research.amnh.org/herpetology/amphibia/index.html>; accessed in Jan. 2013.

Gosner, K.L. 1960. A simplified table for staging anuran embryos and larvae with notes on identification. Herpetologica 16(2): $183-190$

Lavilla, E.O. 1990. The Tadpole of Hyla nana. Journal of Herpetology 2(24): 207-209.

Lourenço-de-Moraes, R.; Campos, F.S. \& Toledo, L.F. 2012. The tadpole of Dendropsophus haddadi (Bastos \& Pombal 1996) (Hylidae: Hylinae). Zootaxa 3476: 86-88.

Mercês, E.A. \& Juncá, F.A. 2010. Girinos de três espécies de Aplastodiscus Lutz, 1950 (Anura - Hylidae) ocorrentes no Estado da Bahia, Brasil. Biota Neotropica 10(4): 167-172.

Nascimento, F.A.C.; Lisboa, B.S.; Skuk, G.O. \& Sá, R.O. 2010. Description of the tadpole of Proceratophrys renalis (MirandaRibeiro, 1920) (Anura: Cycloramphidae). South American Journal of Herpetology 5(3): 241-248.

Pugliese, A.; Alves, A.C.R. \& Carvalho-e-Silva, S.P. 2000. The tadpoles of Hyla oliveirai and Hyla decipiens with notes on the Hyla microcephala group (Anura, Hylidae). Alytes 18(1-2): 7380.

Rossa-Feres, D.C. \& Nomura, F. 2006. Caracterização e chave taxonômica para girinos (Amphibia: Anura) da região noroeste do estado de São Paulo, Brasil. Biota Neotropica 1(6): http://dx.doi.org/10.1590/S1676-06032006000100014.

Vera Candioti, M.F. 2007. Anatomy of anuran tadpoles from lentic water bodies: systematic relevance and correlation with feeding habits. Zootaxa 1600: 1-175. 